\title{
The effectiveness of technological methods for the cultivation of oil flax
}

\author{
Maria Karpova ${ }^{1}$, Nina Roznina $^{1}$, Dmitriy Paliy ${ }^{1}$, Elena Poverenova ${ }^{1}$,Valentina Borovinskikh ${ }^{2}$ \\ ${ }^{1}$ Kurgan State Agricultural Academy by T. S. Maltsev, Kurgan region Ketovsky district, Lesnikovo village, main building, Kurgan, \\ Russia \\ ${ }^{2}$ Kurgan State University, ul.Sovetskaya 63, p. 4, Kurgan, Russia
}

\begin{abstract}
Oilseeds and products of their processing, both for the individual and for the entire economy of the country, are of great importance. This is also due to the fact that in recent years there has been an increase in interest in the production of oilseeds due to the high demand for oilseeds and products of their processing on the world and Russian markets. Oil flax provides a high-quality technical oil used in the paint and varnish and leather and footwear industries for the production of paints, varnishes, putties, soaps, oilcloths, waterproof fabrics, linoleum and rubber substitutes. It is also used in metalworking, electrical engineering and other industries. Flax is an environmentally friendly culture. When cultivating it, a minimum amount of chemical protection and fertilizers is required. Flax crops free the earth from heavy metals and radionuclides. Flax seeds obtained from contaminated land do not even show any trace of radiation. In the last three years, a kind of oil flax boom has been observed in Russia. The high demand for products made from it makes it very profitable to grow, which explains the annual growth of the cultivated area.The article provides an economic substantiation of the project for organizing the cultivation of oil flax. With the help of technological maps, the costs of production are calculated.
\end{abstract}

\section{Introduction}

Agricultural production in our country does not fully meet the needs of the population in vegetable oils, and animal husbandry lacks vegetable proteins. This is the main problem of food supply in our country. It is possible to solve these problems by increasing the volume of cultivation of such oilseeds as oilseed flax[1]. At the heart of the cultivation of crops is a set of technological operations that require economic justification and benefits. The essence of economic efficiency is obtaining the maximum amount of products from each hectare of land with the least labor and cost per unit of production. This is the final effect from the use of the means of production and living labor, the return on total investment [2]. The economic efficiency of crop production is characterized by the most important economic indicators: yield, costs invested per hectare of sowing, production costs, conditional net income or cost recovery and profitability of production.

\section{Problem Statement}

The main problem of food supply in our country is the low supply of vegetable oil and vegetable protein. These problems can be solved by increasing the volume of cultivation of oilseeds such as oilseed flax.
The cultivation of crops is accompanied by a set of technological operations that must find economic justification and benefits.

\section{Research Questions}

To assess the economic efficiency of agriculture, specific indicators are needed that reflect the influence of various factors on the production process. It should take into account its features that affect the final results [3].

Only a systematic approach makes it possible to conduct a comprehensive analysis and draw reliable conclusions about the main directions of increasing the economic efficiency of agricultural production [4].

The economic efficiency of agricultural production is characterized by a system of natural and cost indicators. The initial indicators, of course, are natural indicators: the productivity of agricultural crops and the productivity of farm animals. Achieving a higher level, increasing the productivity of animals meet the main task of agriculture - to increase the production of use values in order to increase the living standards of the people. The size of the yield has a direct impact on the value of other indicators [5].

However, natural indicators reflect only one side of the achieved efficiency. To identify the economic effect, it is also necessary to know the total labor costs that ensured the receipt of a given yield or productivity of animals. The same level of productivity can be achieved

\footnotetext{
*Corresponding author:mdusheva@rambler.ru
} 
with different inputs of labor and resources. Moreover, with the same yield, there may be different product quality, which affects the production efficiency. In order to obtain commensurate values of the costs of material resources and production results, the volume of production is converted into a value form. Cost indicators have not only accounting, but also economic significance, since they participate in the development of commodity-money relations, and the product of production acts as a commodity in the market. The main cost indicators of the economic efficiency of agricultural production are gross income, net income and profit.

\section{Purpose of the Study}

The main goal is to determine the economic and bioenergy efficiency of the studied elements of the phytosanitary technology for the cultivation of oil flax.

\section{Research Methods}

When writing a scientific work, the following research methods were used: the method of economic comparison, which is based on the calculation of technological maps; normative analysis.

\section{Findings}

Agricultural production in our country does not fully meet the needs of the population in vegetable oils, and animal husbandry - in vegetable proteins. This is the main problem of food supply in our country. It is possible to solve these problems by increasing the volume of cultivation of such oilseeds as oilseed flax. The basis of the cultivation of agricultural crops contains a set of technological operations that require economic justification and benefits.

The propagation of new varieties is one of the most affordable, energy-saving and economically justified ways to increase the gross grain harvest in agricultural production. Its contribution to the increase in yield can reach $60 \%$. However, in production conditions, the potential of the variety is realized only by $25-30 \%$, due to insufficient consideration of the genetic characteristics of plants during their cultivation [3].

Each variety has certain requirements for growing conditions. Therefore, for their effective use, it is necessary to develop appropriate varietal agricultural equipment in specific soil and climatic conditions. Moreover, determining the optimal criteria for the intensity of technology for a particular variety will increase energy efficiency and ensure the greatest payback of the resources spent. The variety should form economically justified crop increases for additional investments in agricultural machinery, which is especially important in the current market conditions, as well as have plasticity and stable yield in different years according to meteorological conditions [Karpova M. V., 2015].

The study of any issue on crop cultivation technologies, in addition to private agronomic issues, must necessarily be accompanied by an economic analysis, since they cannot be used in production if they are unprofitable.

The essence of economic efficiency is to obtain the maximum amount of production from each hectare of land at the lowest cost of labor and money per unit of production. This is the final effect of the use of means of production and live labor, the return on total investments.

The economic efficiency of crop production is characterized by the most important economic indicators: yield, costs invested per hectare of sowing, cost of production, conditional net income or cost recovery and profitability of production.

Assessment of the economic efficiency and effectiveness of the cultivation of oilseed flax is one of the most important issues of interest to the heads of flax farms and, above all, those who are at the initial stage of the formation of production

To determine the economic efficiency of the techniques we are studying, it is necessary to establish the option in which there will be the highest yield, minimum costs, maximum profit per 1 hectare of sowing and the highest return on costs. The calculation of the costs required for the production of flax seeds was based on the data of technological maps, taking into account the prices prevailing at the time of writing of this work for seed material, fuels and lubricants, depreciation of machinery and equipment, wages of workers. The economic efficiency of the cultivation of oil flax was calculated based on the sale price of finished products in 2020. The sale price and the resulting yield directly influenced the calculation of the economic efficiency of the cultivation of oil flax varieties. The calculation of economic efficiency was made on average for three years 2018-2020 (Table 1).

Evaluation of the economic efficiency and effectiveness of the cultivation of oil flax is one of the most important issues of interest to the heads of flax farms and, above all, those who are at the initial stage of production development [7]. Best indicators of the economic efficiency of the yield of oil flax seeds were obtained on the varieties Severny and Uralsky. The cost of costs per 1 centner was from 547.7 rubles for the variety Uralsky and up to 921.9 rubles for the variety Raciol. Our calculations and analysis of the economic efficiency of promising domestic and foreign varieties of oil flax showed that the cultivation of oil flax in the southern Trans-Urals is economically profitable for all the options under study, the cost recovery ranged from 2.17 to 3.65 rubles. 
Table 1.Economic efficiency of promising varieties of oil flax (Kurgan State Agricultural Academy, 2018-2020)

\begin{tabular}{|c|c|c|c|c|c|c|c|}
\hline \multirow[t]{2}{*}{ Variety } & \multirow{2}{*}{$\begin{array}{l}\text { Productivity } \\
{[\mathrm{t} / \mathrm{ha}]}\end{array}$} & \multicolumn{2}{|c|}{$\begin{array}{l}\text { Production costs } \\
\text { [RUB] }\end{array}$} & \multirow{2}{*}{$\begin{array}{l}\text { The cost of } \\
\text { production from } 1 \\
\text { hectare }[\text { RUB] }\end{array}$} & \multicolumn{2}{|c|}{$\begin{array}{l}\text { Conditional net income } \\
\text { [RUB] }\end{array}$} & \multirow[t]{2}{*}{$\begin{array}{l}\text { Payback of } \\
\text { costs [RUB] }\end{array}$} \\
\hline & & per 1 ha & per $1 \mathrm{c}$ & & per 1 ha & per $1 \mathrm{c}$ & \\
\hline $\begin{array}{l}\text { North } \\
\text { (standard) }\end{array}$ & 2.62 & 15975 & 609.7 & 52400 & 36425 & 1390.3 & 3.28 \\
\hline Itil & 2.16 & 15653 & 724.7 & 43200 & 27547 & 1275.3 & 2.76 \\
\hline VNIIMK 620 & 1.95 & 15506 & 795.2 & 39000 & 23494 & 1204.8 & 2.52 \\
\hline LM 98 & 2.24 & 15709 & 701.3 & 44800 & 29091 & 1298.7 & 2.85 \\
\hline Lirina & 2.28 & 15737 & 690.2 & 45600 & 29863 & 1309.8 & 2.90 \\
\hline Ural & 2.96 & 16213 & 547.7 & 59200 & 42987 & 1452.3 & 3.65 \\
\hline Ural yellow & 2.28 & 15737 & 690.2 & 45600 & 29863 & 1309.8 & 2.90 \\
\hline Raciol & 1.66 & 15303 & 921.9 & 33200 & 17897 & 1078.1 & 2.17 \\
\hline
\end{tabular}

The structure of the cost of production includes production costs, which are grouped by elements, articles, place of origin, planning and accounting objects. Cost elements are understood as costs that are homogeneous in their economic content [8]. Production costs consist of the following elements: labor costs with deductions for social needs; material costs; depreciation of fixed assets; other costs. According to the gross collection of products (main, secondary, associated) in kind, its cost is calculated at the current selling prices, taking into account the quality.

Table 2.Economic efficiency of oilseed flax variety Severny when using biological products and micronutrient fertilizers, 2018-2020

\begin{tabular}{|c|c|c|c|c|c|c|c|}
\hline \multirow[b]{2}{*}{ Variant } & \multirow{2}{*}{$\begin{array}{l}\text { Productivity } \\
{[\mathrm{t} / \mathrm{ha}]}\end{array}$} & \multicolumn{2}{|c|}{$\begin{array}{l}\text { Production } \\
\text { costs [RUB] }\end{array}$} & \multirow{2}{*}{$\begin{array}{ll}\text { The cost of } \\
\text { production } \\
\text { from } & 1 \\
\text { hectare } & \\
\text { [RUB] } & \\
\end{array}$} & \multicolumn{2}{|c|}{$\begin{array}{l}\text { Conditional net } \\
\text { income [RUB] }\end{array}$} & \multirow{2}{*}{$\begin{array}{l}\text { Payback } \\
\text { of costs } \\
\text { [RUB] }\end{array}$} \\
\hline & & $\begin{array}{l}\text { per } 1 \\
\text { ha }\end{array}$ & $\begin{array}{l}\text { per } 1 \\
\text { c }\end{array}$ & & $\begin{array}{ll}\text { per } & 1 \\
\text { ha } & \end{array}$ & per $1 \mathrm{c}$ & \\
\hline 1. Control (no processing) & 1.61 & 10595 & 658.1 & 32200 & 21605 & 1341.9 & 3.04 \\
\hline $\begin{array}{l}\text { 2. Seed treatment } 21 / \mathrm{t} \text { microbiological } \\
\text { preparation Biocomposite-correct }+ \text { soil } \\
\text { tillage before sowing } 2 \mathrm{l} / \mathrm{ha}\end{array}$ & 1.99 & 12443 & 625.3 & 39800 & 27357 & 1374.7 & 3.20 \\
\hline $\begin{array}{l}\text { 3. Biocomposite-correct, soil tillage } \\
\text { before sowing: } 21 / \text { ha }+ \text { micronutrient } \\
\text { fertilizers IntermagProfiOleistye, } \\
\text { processing by vegetation } 2 \mathrm{l} / \mathrm{ha}\end{array}$ & 2.26 & 13612 & 602.3 & 45200 & 31588 & 1397.7 & 3.32 \\
\hline $\begin{array}{l}\text { 4. Biocomposite-correct, soil tillage } \\
\text { before sowing: } 21 / \text { ha }+ \text { tillage during } \\
\text { vegetation Biocomposite-correct } 2 \mathrm{l} / \mathrm{ha}\end{array}$ & 2.26 & 14058 & 622.0 & 45200 & 31142 & 1378.0 & 3.22 \\
\hline $\begin{array}{l}\text { 5.Processing of seeds } 21 / \mathrm{t} \\
\text { Biocomposite-correct }+ \text { soil treatment } \\
\text { before sowing } 21 / \text { ha }+ \text { processing by } \\
\text { vegetation, Biocomposite-correct } 21 / \\
\text { ha }+ \text { processing by vegetation } \\
\text { IntermagProfiOleistye } 2 \mathrm{l} / \mathrm{ha}\end{array}$ & 2.61 & 15439 & 591.5 & 52200 & 36761 & 1408.5 & 3.38 \\
\hline $\begin{array}{l}\text { 6. Treatment of seeds } 21 / \mathrm{t} \\
\text { Biocomposite-correct; micronutrient } \\
\text { fertilizers IntermagProfiOleistye, } \\
\text { processing by vegetation } 21 / \mathrm{ha}\end{array}$ & 2.46 & 12326 & 501.1 & 49200 & 36874 & 1498.9 & 3.99 \\
\hline
\end{tabular}

The best indicators of the economic efficiency of the yield of oil flax seeds were obtained on the following variants: Treatment of seeds $21 / \mathrm{t}$ Biocompositecorrect; micronutrient fertilizers IntermagProfiOleistye, treatment for vegetation $2 \mathrm{l} / \mathrm{ha}$; Seed treatment $2 \mathrm{1} / \mathrm{t}$ Biocomposite-correct + soil tillage before sowing $21 /$ ha + treatment for vegetation, Biocomposite-correct $21 /$ ha + treatment for vegetation
IntermagProfiOleistye $21 /$ ha. The payback of costs for these options was 3.99 and 3.38 rubles, respectively.Evaluation of the economic performance and efficiency of the cultivation of oil flax is one of the most important issues of interest to the heads of flax farms and, above all, those who are at the initial stage of the formation of production (Table 3 ). 
Table 3.Economic efficiency of the oilseed flax variety Severny when using modern agrochemicals, 2018-2020.

\begin{tabular}{|c|c|c|c|c|c|c|c|}
\hline \multirow{2}{*}{ Variant } & \multirow{2}{*}{$\begin{array}{l}\text { Productivity } \\
\text { [t/ha] }\end{array}$} & \multicolumn{2}{|c|}{$\begin{array}{l}\text { Production costs } \\
\text { [RUB] }\end{array}$} & \multirow{2}{*}{$\begin{array}{l}\text { The cost of } \\
\text { production from } 1 \\
\text { hectare [RUB] }\end{array}$} & \multicolumn{2}{|c|}{$\begin{array}{ll}\text { Conditional } & \text { net } \\
\text { income [RUB] } & \\
\end{array}$} & \multirow{2}{*}{$\begin{array}{l}\text { Payback of } \\
\text { costs } \\
\text { [RUB] }\end{array}$} \\
\hline & & $\begin{array}{l}\text { per } 1 \\
\text { ha }\end{array}$ & per $1 \mathrm{c}$ & & per 1 ha & per $1 \mathrm{c}$ & \\
\hline Control & 1.72 & 10619 & 6173.8 & 34400 & 23781 & 1382.6 & 3.24 \\
\hline Fertix brand A 1 1/ha & 2.27 & 11831 & 5211.9 & 45400 & 33569 & 1478.8 & 3.84 \\
\hline Borno N 1 l/ha & 2.16 & 11534 & 5339.8 & 43200 & 31666 & 1466.0 & 3.75 \\
\hline $\begin{array}{l}\text { Potassium lignohumate } \\
\text { grade B } 0.5 \mathrm{l} / \mathrm{ha}\end{array}$ & 2.42 & 11484 & 4745.5 & 48400 & 36916 & 1525.5 & 4.21 \\
\hline $\begin{array}{l}\text { Fertix brand A } 1 \text { l/ha }+ \\
\text { Borno N } 1 \text { 1/ha }\end{array}$ & 2.86 & 12587 & 4401.0 & 57200 & 44613 & 1559.9 & 4.54 \\
\hline $\begin{array}{l}\text { Fertix grade A } 1 \text { l/ha }+ \\
\text { Lignohumate grade B } \\
\text { potash } 0.51 / \text { ha }\end{array}$ & 3.08 & 12509 & 4061.4 & 61600 & 49091 & 1593.9 & 4.92 \\
\hline $\begin{array}{ll}\text { Organic } & \text { silicon } \\
0.003 \mathrm{l} / \mathrm{ha} & \\
\end{array}$ & 2.38 & 11461 & 4815.5 & 47600 & 36139 & 1518.4 & 4.15 \\
\hline
\end{tabular}

The best indicators of the economic efficiency of the yield of the oilseed flax variety Severny were obtained in the variants of combined application Fertix grade A 1 1/ha + Lignohumate grade B potassium 0.5 1/ha when processing flax plants in the "herringbone" phase and Fertix grade A 1 1/ha + Borno N 1 1/ha, the payback of costs for these options was 4.92 rubles and 4.54 rubles, respectively.

\section{Conclusion}

Our calculations and analysis of the economic efficiency of the cultivation of oil flax with the use of modern herbicides and biological products in the Kurgan region shows that the use of modern agrochemicals for the protection of oil flax increases yields and, despite the increase in costs, increases net income and cost recovery in the variants of experience with the use of agrochemicals according to compared with control.

\section{References}

1. A.Yu. Anfalova, M.V. Pavlutskikh, M.A. Sumarokova Priority areas of scientific and technological development of the agroindustrial complex: collection of works of the international scientific and practical online conference, Novosibirsk, p. 13-18, (2020).

2. N.V. Roznina, M.V. Karpova, S.G. Dunicheva, M.I. Zakharova, Yu. I. Ovchinnikova, E.N. Lapina, International Transaction Journal of Engineering. Management. \&Applied Sciences \& Technologies,11(14), 1-10, (2020)

3. A. I. Kapinos et al. Vestnik NGAU. 1 (30), 118 123, (2014)

4. N. A. Kuptsevich, Bulletin of Kurgan State Agricultural Academy, 3 (27), 38-43, (2018).
5. S.N. Nikulina Advances in Economics, Business and Management Research (AEBMR), 147, 253-256, (2020).

6. M.M. Voityuk, V.A. Zubtsov, I.Z. Minevich, L.L. Osipova, Information Bulletin of the Ministry of Agriculture of the Russian Federation,10, 43-45, (2015)

7. A.P. Kolotov, O.V. Sinyakova Agro-industrial complex of Russia, 72/1, 92-96, (2015).

8. I.N. Mikolaichik, L.A. Morozova, V.G. Kakhikalo, L.Yu. Ovchinnikova, L.P. Yarmots, Yu.A. Karmatskikh,V.I. Charykov, International Transaction Journal of Engineering, Management and Applied Sciences and Technologies, 11, 2, (2020).

9. F.M. Galkin, V.I. Khatnyansky, N.M. Tishkov, V.T. Piven, V.D. Shaforostov Breeding, seed production, cultivation and harvesting technology (Krasnodar, 2008).

10. A.Yu. Anfalova, N.D. Gushchenskaya, A.U. Esembekova Resource saving. Efficiency. Development: materials of the $V$ Republican scientific and practical conference. Donetsk, p. 14-22 (2020).

11. N. Roznina, M. Karpova, A.Shulgina, V. Borovinskikh, A.Volkova, The Role of Economic Science in Ensuring Sustainable Development of Agriculture 10001 (2021)

12. A.P. Kolotov, S.L. Eliseev Perm Agrarian Bulletin, 1 (5), 15-19, (2014).

13. V. Komissarova Bulletin of Kurgan State Agricultural Academy, 3 (3), 33-36,(2012)

14. G.A. Michkina, G.A. Popova, N.B. Rogalskaya Fiber flax cultivation technology in Siberia. (Tomsk: Wind, 2012)

15. G.K. Duskaev, S.G. Rakhmatullin, N.M.Kazachkova, Y.V. Sheida, I.N. Mikolaychik, L.A. Morozova, B.H. Galiev Veterinary World,11(10), 1416-1422, (2018) 